\title{
CORRUPTION AND INTERNAL CONTROL WEAKNESSES. CASE STUDY ROMANIA
}

Luminița IONESCU

Spiru Haret University, Bucharest

E-mail: luminita.ionescu@ spiruharet.com

\begin{abstract}
Corruption represents one of the major causes of poverty all over the world and European Union is fighting against it. In the last few years, the corruption phenomenon registered a high level in some European countries and became one of the most problematic factors for doing business, due to the evolution of the perceived top five global risks: interstate conflict and regional consequences, extreme weather events, failure of national governance, state collapse or crises, high structural unemployment or underemployment (WEF-Global Risk Report 2015, p. 14).

One of the modalities in combating corruption is implementing the internal control and most of the governments and organizations adopted strong control techniques. Most of the control weaknesses are related to the financial procedures and the number of controllers. Some of the controllers do not have enough financial expertise or do not understand the importance of informatics systems.
\end{abstract}

Keywords: corruption, government, fraud, internal control

JEL Classification: $\mathrm{D}_{72}, \mathrm{H}_{11}, \mathrm{H}_{26}, \mathrm{M}_{42}$

\section{Introduction}

In this paper we investigate the relation between economic risks, corruption, and the internal control weaknesses. The global economic risks have changed in the last five years and the companies must implement a strong internal control in order to reduce corruption, fraud and inequality. Fraud could be a cause of growing corruption, but fighting corruption in many countries has proved difficult (Treisman, D., 2000).

There are also more likely to be identified internal control weakness, if the controllers are not independent. Also, it would be important to implement external control in order to prevent the fraud risks.

In Romania, corruption is considered one of the problematic factors for doing business, but the modernization of accounting systems and new European regulations improved the financial system and reduced the inefficient government bureaucracy. 


\section{Literature Review}

This paper is related to several recent papers on the determinants of internal control, corruption and economic risks:

Global Risks Report 2015 (World Economic Forum) presented how fragile societies are under a lot of pressure. A major driver of social fragility is big socioeconomic inequality within countries, and rising structural unemployment drives both inequality and social pressures. According to this Report, there are some global economic risks of highest concern, such as: unemployment or underemployment, fiscal crises, asset bubble, failure of financial mechanism or institution, energy price shock, deflation, failure of critical infrastructure, unmanageable inflation. European countries are still recovering after the recent economic crises and the global financial system is undergoing massive structural change. In this context, we could observe how banks' regulatory rules have been revised, resulting in stronger capital requirements, the first-ever globally agreed liquidity standards, and new standards for constraining large exposures and improving risk management (Global Risk Report 2015, p. 19).

The international community is finalizing a basic solvency requirement for global insurers who are systemically important, because the bank and the insurer system are affecting the global economy. International accounting standards are being changed, in particular to make loss recognition more forward-looking (such as IFRS9) and COSO Internal Control Framework has been updated.

Zhang, Yan et al (2007) in "Audit committee quality, auditor independence, and internal control weaknesses" explained how the relation between audit committee quality and internal control weaknesses is being developed. They observed how the audit committee not only plays an important monitoring role to assure the quality of financial reporting, but also serves as an important governance mechanism. It was discovered that firms with high-quality audit committees are less likely to have internal control weaknesses than firms with low-quality audit committees. The research presented some firms that are more likely to be identified with an internal control weakness, if their audit committees have less financial expertise or, more specifically, have less accounting financial expertise and nonaccounting financial expertise. In this case study, it was identified that internal control is weak, if the auditors are more independent and other firms with recent auditor changes are more likely to have internal control weaknesses.

The Updated COSO Internal Control Framework (2013) continues to emphasize the importance of management's judgment in evaluating the effectiveness of a system of internal control. The Framework explained how external parties, including external auditors and regulators, are not part of the system of internal control and cannot be considered a source of detection and assessment of internal control deficiencies. In this case, the responsibility for identifying and assessing internal control deficiencies rests with the controllers or internal auditors, in the normal course of companies' activities. According to the Principle 8 of Internal Control, many companies integrate their evaluation of the 
effectiveness of controls mitigating fraud risk with the evaluation of other controls embedded within the organization's processes. It is generally accepted that control activities are an integral part of making business processes work, but control activities are in place within the process to reduce "financial reporting assertion risks" to an acceptable level, including the risk of fraud. In conclusion, the COSO Internal Control - Integrated Framework provides an overall framework for addressing the effectiveness of internal control in providing reasonable assurance that operational, reporting and compliance objectives are achieved.

\section{The Evolution of Corruption in European Countries}

We noticed that corruption is growing in European countries despite the efforts of European governments, public institutions and non-profit organizations. Cross-country data for European countries is used to analyse the role of government bureaucracy, tax regulations and the effect of policy instability. According to the Global Corruption Barometer (2013), every day, all over the world, ordinary people bear the cost of corruption and in many countries corruption affects people from birth until death. It was observed that citizen action can lead to the exposure of corrupt acts and put pressure upon reluctant governments to do more in the fight against corruption. In this global context, The Global Corruption Barometer (2013) underscores the pressing desire of citizens to get involved in stopping corruption.

Fig. no. 1. The evolution of corruption by regions

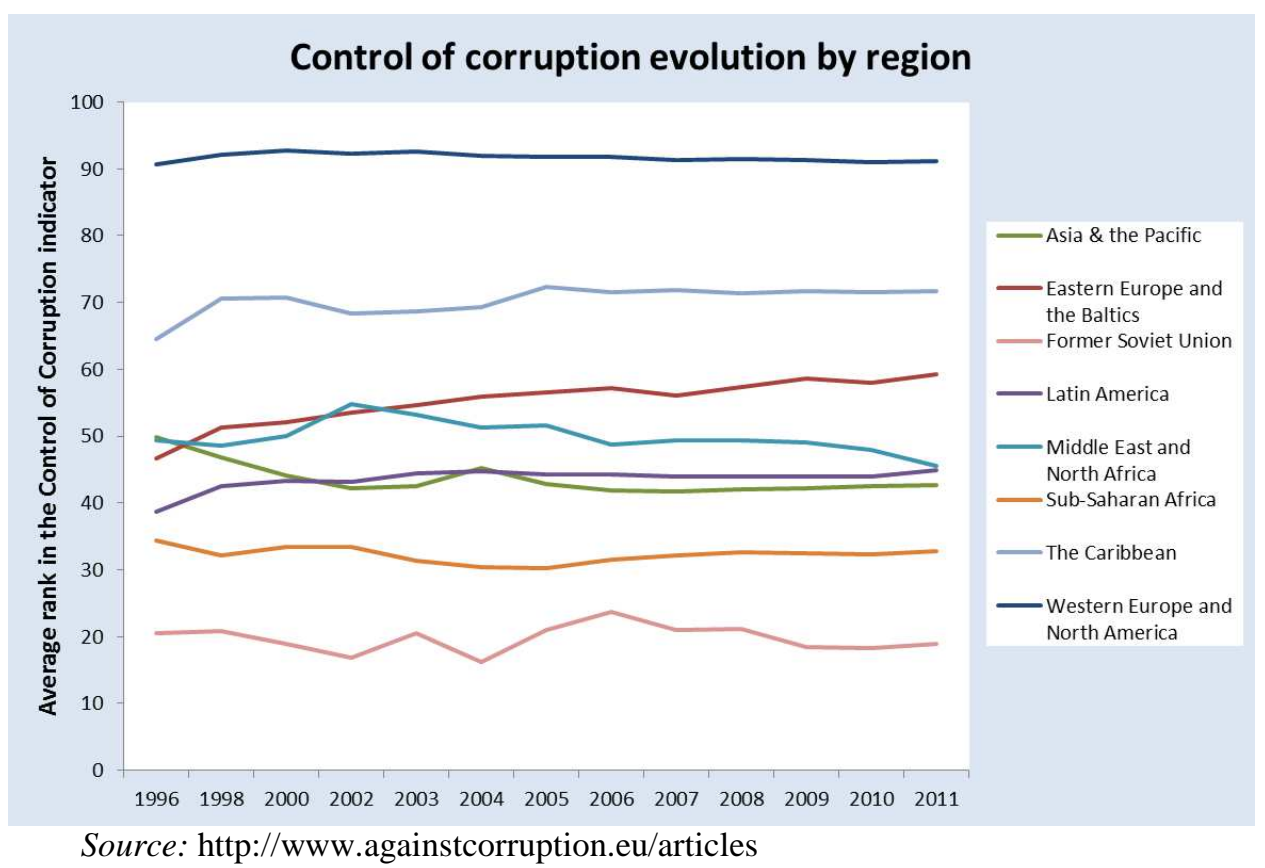


Corruption continues to be a challenge for Europe - a phenomenon that costs the European economy around 120 billion euros per year (Anti-Corruption Report 2014). We notice that corruption is increasing in European countries over time, but it is still lower in comparison to developing economies, and the cleanest economies are developed ones. Also mass-media is concentrated on the international dimension of the corruption and how to adopt the effective measures to fight against corruption.

According to the EU treaties (Council of EU - Thematic paper on corruption, Corruption crimes in relation to public procurement, November 2012, p. 5), it is the role of the European Commission to monitor and to verify the correct implementation of EU law into national law. Thus, all the member states are responsible for the correct implementation of EU legislation in order to identify the causes of corruption and the effects over the society.

We could observe in the figure below that corruption is larger in Asian countries and lower in the European countries, as a result of European regulations and enforcement of the internal control and audit for public and economic entities. The red areas are indicated as the corrupted countries and the yellow colour indicates the clean countries. We notice that the North European area is very clean compared to the South-East European area:

Fig. no. 2. Corruption in Europe

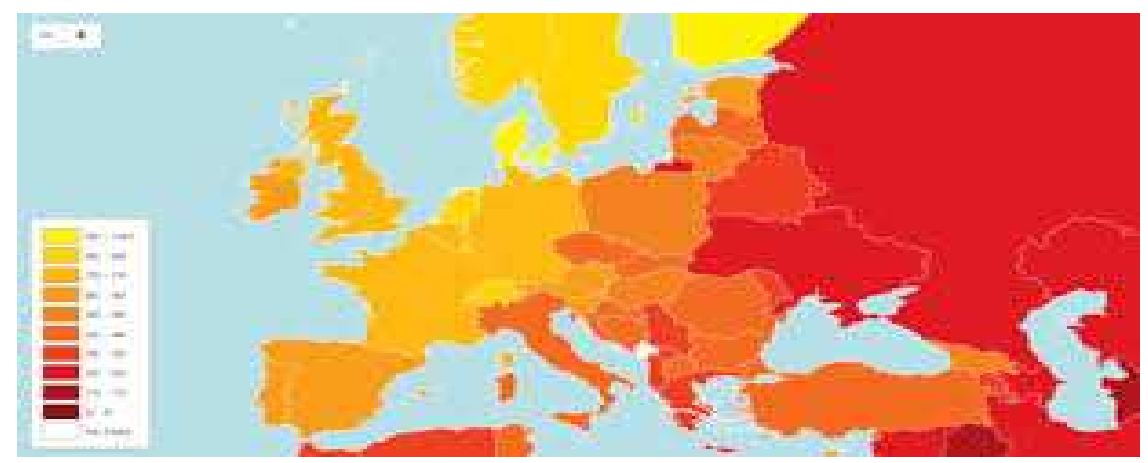

Source: http://www.europe-forum.info/index

There are some candidate countries to join EU, where corruption index is significant in the last few years, as a consequence of international crises, growing bureaucracy and political instability. For this reason EU adopted a set of conditions to reduce corruption, which have to be met by the candidate countries in order to join the EU. The EU candidate countries are Iceland, Macedonia, Montenegro, Serbia and Turkey. There have been several years since the accession negotiations were opened with these countries, as follows: Turkey in October 2005, with Iceland in July 2010 and with Montenegro in June 2012. EU supports reforms for the candidate countries with financial help and the Instrument for Pre-accession Assistance (IPA). According to the EU data base, for the period 2007-2013 IPA 
had a budget of some $€ 11.5$ billion; its successor, IPA II, will be built on the results already achieved by dedicating $€ 11.7$ billion for the period 2014-2020.

Fig. no. 3. Corruption Perception Index for Candidate Countries

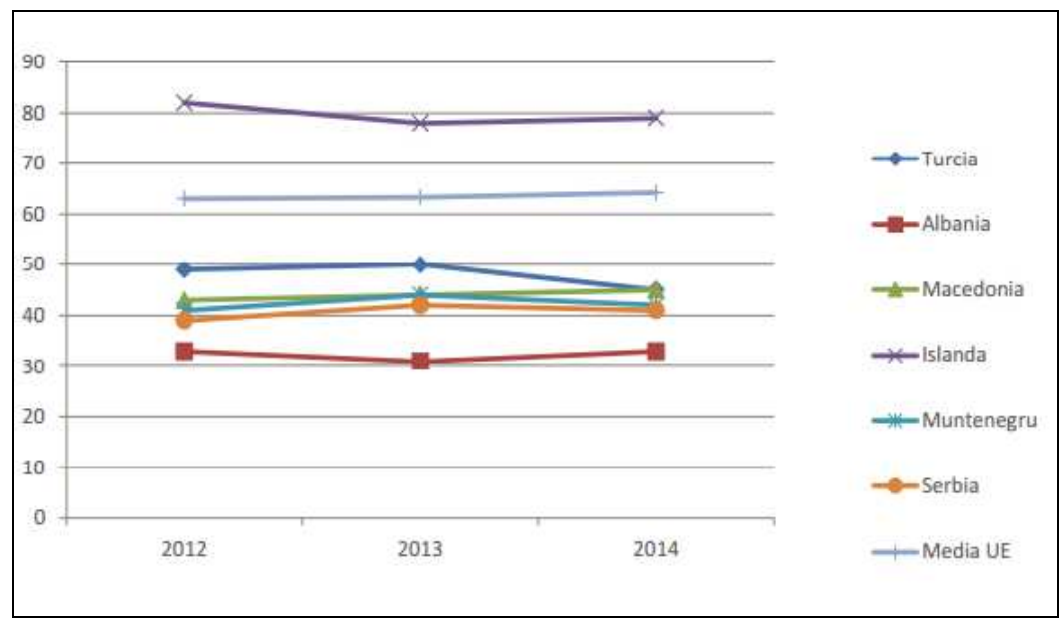

Source: http:// www.transparency.org.ro/politici_si_studii/indici/ipc/2014

The Corruption Perceptions Index presents on a scale from 0 (perceived to be highly corrupt) to 100 (perceived to be very clean) the corruption all over the world and is based on expert opinions of public sector. We observe in the figure no. 3 how scores for Turkey is reduced in Turkey from 50 in 2012 to 45 in 2014. In the same time, Island is a very clean country with a very good score in 2012 (82) and almost the same in 2014 (79). The rest of the candidate countries maintain the same score during 2012-2014.

\section{The Evolution of Corruption in Romania}

Corruption in Romania is one the barriers of the economic development with long term consequences on the Romanian society. Unfortunately, the last economic crisis had a large and lasting impact on the Romanian economy (European Commission - Country Report Romania 2015, p. 4). After a strong economic growth in the period 2003-2008, a large drop follow in 2009 and a potential growth has started with a very timid recovery. According to the European Commission, the economic growth is forecast to reach $2.9 \%$ in 2019 , which is $0.5 \%$ lower than the average potential growth in the pre-crisis period.

Post-crisis the tax mix has improved, but tax policy is changing frequently and revenue collection remains weak. This tax rates instability is a major cause for the low level of investment in Romania and remains above EU average. According to EU-Country Report Romania 2015, EU funds' absorption is lagging behind, at only $52.2 \%$ of the available structural and cohesion funds as of end of 2014 . 
However, corruption is still one of the most problematic factors of doing business in Romania (table no. 1).

Fig. no. 4. The most problematic factors for doing business in Romania

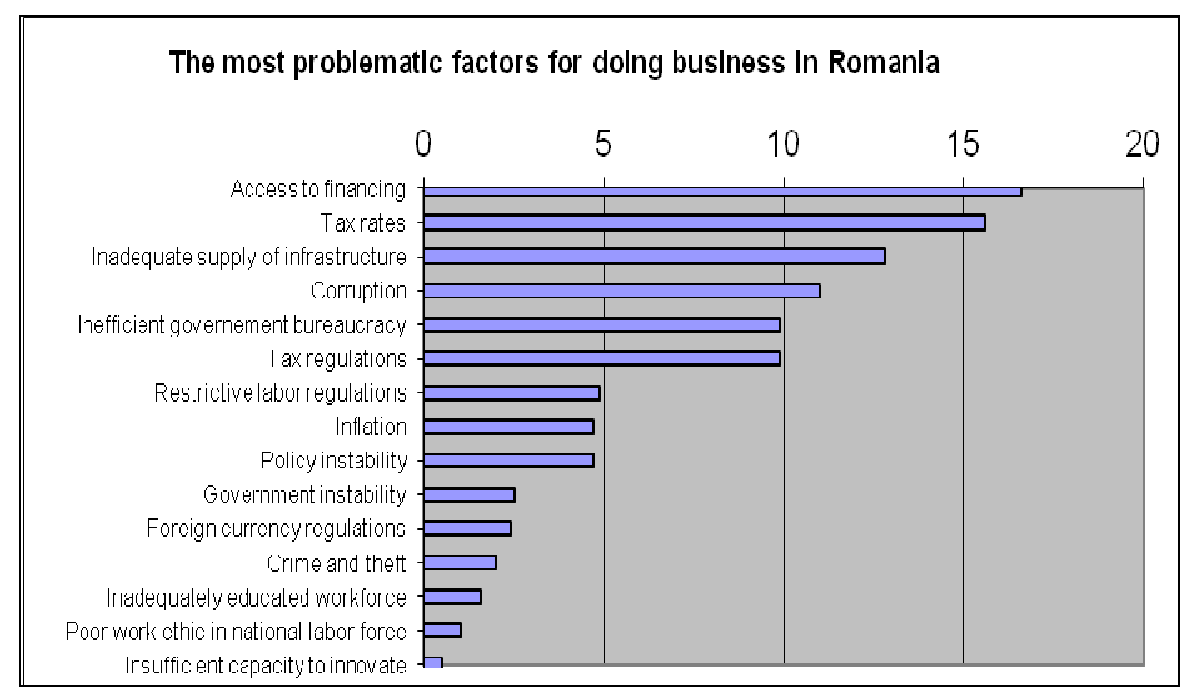

Source: Global Competitiveness Report 2014-2015, WEF Geneva 2015

Despite these problematic factors, we could observe that corruption has a constant level in Romania, due to the government efforts to maintain a political and economic stability (Ionescu, L., 2012). The corruption perception index in Romania (43) is much lower than the EU average (64.21), but we observe an improvement from 2012 (44) to 2014 (43) and it is estimated to drop in the next few years. The figure no. 4 presents the evolution of corruption perception index for the period 2012-2014:

Fig. no. 5. The Evolution of Corruption Perception Index in Romania

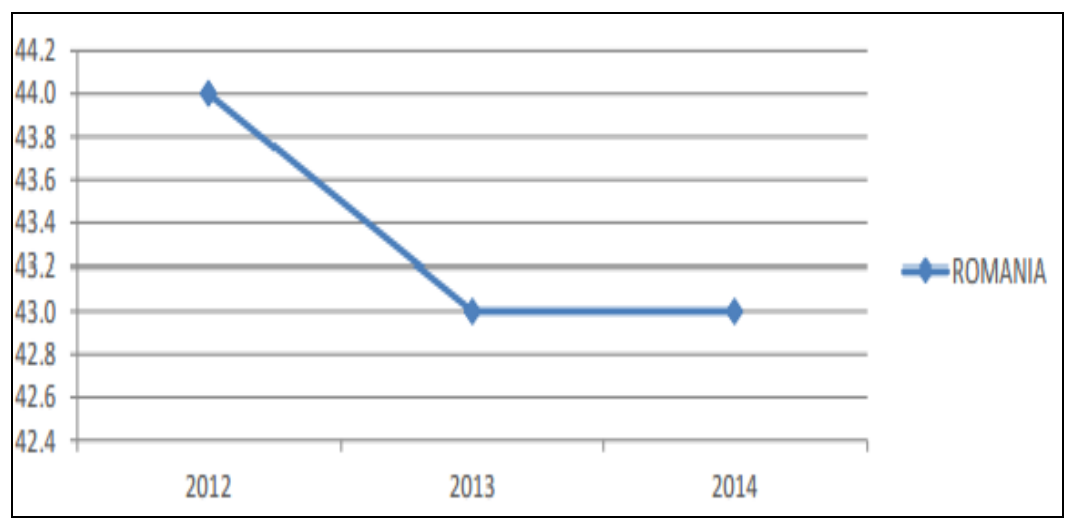


There are estimations that the corruption perception in Romania will drop in the next few years due to the strong implementation on internal control, internal audit and effective cooperation, between central and local public authorities, with the involvement of National Agency for Fiscal Administration (ANAF) and National Office for Prevention and Control of Money Laundering (ONPCSB).

\section{Internal Control Weaknesses in Romania}

According to the COSO framework, internal control is defined as a process, effected by an entity's board of directors, management and other personnel, designed to provide reasonable assurance regarding the achievement of objectives. Despite the long history of internal control, the economic crisis from 2008 to 2010 reveals some weaknesses of the internal control in most European countries and especially in Romania.

Internal control consists of five interrelated components, derived from the way management runs a business, and are integrated with the management process. These components are:

- Control Environment

- Risk Assessment

- Control Activities

- Information and Communication

- Monitoring Internal Control

Each entity faces a variety of risks from external and internal sources that must be assessed (COSO framework 2013). According to our experience and business practice, most of the companies did not evaluate the risks in a proper way and registered in their books the non-realistic values for their properties. Also, the overestimated cash-flow and the optimistic figures for their incomes and profits indicated a weakness of internal control. According to some experts, internal control must be evaluated by independent audit (Zhang, Y. and al., 2010).

After the liquidation of many Romanian companies, some weaknesses of internal control were identified:

- poor implementation of internal control;

- lack of sufficient personnel with appropriate qualifications;

- poor implementation of IT systems;

- absence of internal audit;

- no evaluation of internal control by the management.

The quality of internal control is related to the financial indicators of the company and the low level of corruption in the private entities. A good implementation of the internal control is the barrier of spreading corruption and strong premises to develop business in Romania. Firms with stronger internal controls have less corporate corruption (Weili, G. et al., 2014).

Most of the foreign investors are avoiding Romania because corruption is indicated as one of the most problematic factors of doing business. The big companies with greater complexity and scope of operations are more likely to have internal control problems (Domnisoru, S, Vinatoru, S.S., 2011). At the same time, 
small companies are controlled by the manager or by the finance director every month. This explains why the small entities have no corruption and the big entities are exposed to corrupted managers or employees.

\section{Conclusion}

In this paper I presented the evolution of corruption at the European level and national level in the last few years, when most of the countries started a recovery after the economic crisis. In Romania, corruption could be prevented by implementing internal control for big companies, but also to small companies. The weaknesses of internal control are related to poor qualification of accountants and managers, less financial practice of controllers and poor implementation of the IT systems. Most of the transactions nowadays are performed on the internet and employees and management must be very well trained to operate the electronic payments. Corruption affects all segments of society, including businesses, as it affects markets and competition (Magureanu, A.F., 2014), so all governments must implement strong internal control and audit to reduce its effects.

\section{References}

- Ionescu, L. (2012), Principles and Hypothesis on Bureaucracy and Corruption Phenomena, Postdoctoral Research, Romanian Academy, Bucharest, 2012

- Domnişoru, S, \& Vînătoru, S.S. (2011), Auditor Independence, Audit Committee Quality and Internal Control Weaknesses, Revista Tinerilor Economisti, Craiova, pages 7-12

- Măgureanu, A.F. (2014), Few Aspects Regarding Bribery as a Social and Economic Threat, Annals of Spiru Haret, Volume 5(14), issue 3, pages 21-26

- Treisman, D. (2000), The causes of corruption: a cross-national study, Journal of Public Economics, 76(2000)

- Zhang, Y. et al. (2010), Audit Committee Quality, Auditor Independence, and Internal Control Weaknesses, Journal of Accounting and Public Policy, Volume 26, Issue 3, May-June 2007, pages 300-327

- Weili, G. et al. (2014), The Effect of Internal Control on Corporate Corruption: Evidence from China, Working paper, Graduate School of Business Stanford University, http://www.gsb.stanford.edu/sites/default/files/documents/acct_11_14_McVay.pdf

- http://www.coso.org/documents/internalcontrol - Internal Control - Integrated Framework 2013

- http://www.weforum.org/issues/global-risks - World Economic Forum 2015 Global Risk Report

- http://www.anaf.ro/ - Misiune ANAF

- http://ec.europa.eu/enlargement/instruments/overview/index_en.htm - Overview Instrument for Pre-accession Assistance 